\title{
誤差関数に相関係数を用いた機械学習による 赤外スペクトルからの特徴量抽出 \\ Feature Extraction from Infrared Spectroscopy by Machine Learning with Correlation Coefficient as Error Function
}

天谷 貴

Takashi Amagai

石丸 伊知郎

Ichiro Ishimaru

\author{
筑波大学大学院システム情報工学研究科
}

Graduate School of Systems and Information Engineering, University of Tsukuba S1820437@s.tsukuba.ac.jp

\section{香川大学工学部知能機械システム工学科}

Faculty of Engineering, Kagawa University

ishimarueeng.kagawa-u.ac.jp

Keywords: machine learning, error function, correlation coefficient, infrared spectroscopy

\section{Summary}

Conventionally when diagnosing diabetes, experts diagnose using infrared spectroscopy of blood in hospital. Recently, however Blood testing apparatus that are easily available at home are attracting a lot of attention as a preventive medicine. To realize this, it must be easy to measure by an ordinary person at any time. Therefore, I aim to develop a system to analyze infrared spectroscopy acquired from blood by machine learning. Neural networks are also used for pattern recognition problems such as biological signals. However, to discriminate the infrared spectrum, the input becomes high-dimensional, and in a device such as those used at home, large errors are included in the data, so the accuracy drops remarkably. In this study, as a basic study of the analysis of infrared spectroscopy by machine learning, I experimented to extract characteristic peaks from artificially generated data by a new machine learning. In the proposed machine learning, learning is performed by an error back propagation using a correlation coefficient for the error function to extract a waveform more than the value magnitude as a feature value. In this paper, I show the result of the experiment of extracting feature value from artificial data simulating infrared spectroscopy.

\section{1.はじめに}

糖尿病の診断の際，病院などで血液の赤外分光法を利 用した専門家による診断がなされてきた。しかし，今日 では予防医療の観点から，在宅で手軽に利用できる分光 器を用いた血液成分検査装置が高い関心を集めている [Sato 16].この在宅での予防医療を実現するにはこの装 置が専門家なしで自律的に診断できるものでなくてはな らない. そこで, 分光器によって取得した赤外スペクト ルを機械学習により在宅で手軽に分析できるシステムの 開発を目指す. 本研究では, 機械学習による赤外スペク トルの分析の基礎検討として，新たな手法によって人工 的に生成したデータの他, 実際に小型装置によって得た 赤外スペクトルから特徴的なピークを抽出する実験を行 った.

非線形問題に強力な学習能力をもつ誤差逆伝播型ニュ ーラルネットワーク [Rumelhart 86]はさまざまなパター ン認識問題に応用されており，生体信号のパターン認識 問題にも用いられている[Haselsteiner 00, Kelly 91]. しか し，赤外スペクトルを識別するには，入力が高次元とな ってしまうため，与えられたデータの中で表現できる組 み合わせが飛躍的に大きくなり，有限な学習データから
十分な学習を行えず，汎化能力が著しく低下してしまう 問題が生じる( “次元の呪い”)。

これに対し，高次元な入力に対して，ケモメトリック スによる高次元主成分分析を用いた圧縮法がある。この 高次元主成分分析法は複雑なデータの情報をできるだけ 損なわずに次元を圧縮し，データ構造を視覚的にとらえ やすくする解析手法である[Mistek 15]. しかし, 本研究で 解析する赤外スペクトルは在宅で手軽に利用できるよう な分光器から得られた赤外スペクトルであり，得られた データはそのときの測定条件などで，巨大なノイズを含 むと考えられる. 主成分分析でこのような巨大なノイズ に埋もれてしまっている有用な情報を抽出することは困 難である.

そこで本論文では，縦軸が相対強度であり横軸が波長 である高次元データの赤外スペクトルデータに対し，特 徵量となる波形やピークを抽出するため, 值の大きさで なくグラフの形に着目し，誤差関数に相関係数を用いて 誤差逆伝播法を行い，特徴量を示す結合重みを得る。こ の結合重みと学習データの回帰式の傾き・切片，それと 相関係数の三つの值を入力值としたニューラルネットワ 一クにより糖尿病の原因となるグルコースやアルブミン が存在するかの識別，濃度の推定，それと個人の識別を 
行うシステムの提案をする.

特徵量を抽出する際, 単純に与えるスペクトルデータ を平均する方法も考えられるが，この方法では，特徵量 のみの限定した抽出が行えない. そこで，新たに提案す る相関係数を誤差関数とした機械学習では，与えられた 複数のスペクトルから共通したピークの位置が近い波形 の山，または連続した山を，そのピークの高さに関係な く, 限定的に抽出することができる. また，この学習で はデータから共通する特徴的なピーク，波形を可視化す ることができるため, 学習結果の説明能力が重視される ような場面でも有効である.

以下，第 2 章では提案する解析モデルについて述べ, 第 3 章でどのように人工データに特徴量を与えたかの説 明とこれを平均した場合の方法，また提案手法による特 徵量を抽出する実験を行い，第 4 章では実際に小型装置 から得たデータによる実験結果について述べ, 最後にま とめる。

\section{2. 提案手法による糖尿病診断システム}

\section{$2 \cdot 1$ 解析モデル全体の概要}

図 1 に本論文で提案する解析モデルの概要を示す。こ の解析モデルは, 提案する新たな機械学習により構成す る特徵量抽出ネットワークや定量化ネットワークに分け て学習を行う.

与える学習データを横軸が波長, 縦軸が相対強度であ る赤外スペクトルだとすると, 特徵量抽出ネットワーク では，波長軸に対し任意の一定の間隔で分割する。この 分割された区間ごとに学習を行い，区間内に相関がある
場合と相関がない場合で，波形を抽出する区間の選択を 行うことができる。この分割した全区間内で誤差関数に 相関係数を用いて勾配降下法を行い，与えた複数の学習 データから共通する特徴的なピークを抽出する.このと き，区間をまたがってピークが検出される場合でも，以 下の $2 \cdot 3$ 節で述べる区間内の相対強度の補正を行うこ とで，区間をまたがって相対強度がずれることなく抽出 が行える．勾配降下法とは誤差を算出する誤差関数を定 義し, 誤差が小さくなるように誤差関数内のパラメータ の值を調整して理想的なパラメータを取得する手法であ る.この手法はニューラルネットワークの誤差逆伝播法 などに用いられている[Rumelhart 85]. しかし, 区間内で 与えた複数のグラフに相関が低い場合は収束しないこと になる，そこである一定以上の更新を行っても収束しな い場合はその区間で 0 を代入するなどして，この区間で の抽出のデータ選択を外す必要がある. 以上のような学 習を行うことで，与えた複数の学習データからピークの 位置が近い波形の山，または連続した山を限定的に抽出 することができる.

次に，学習を終えた結合重みから識別するテストデー 夕に対し相関係数, 回帰式の傾き・切片の三つの值を取 得する. このように二つのデータから三つの特徵量に落 とす方法は正規化相関という手法であり，工業画像処理 の分野で二次元画像に対しテンプレート照合のため研究 されてきた手法である[Bamea 72, Silver 87]. テンプレー 卜照合とは，テンプレート画像と類似した画像を対象画 像内から探し出す処理である，画像解析の場合，縦軸が 輝度值で横軸が画像のピクセル数となる．相関係数はテ

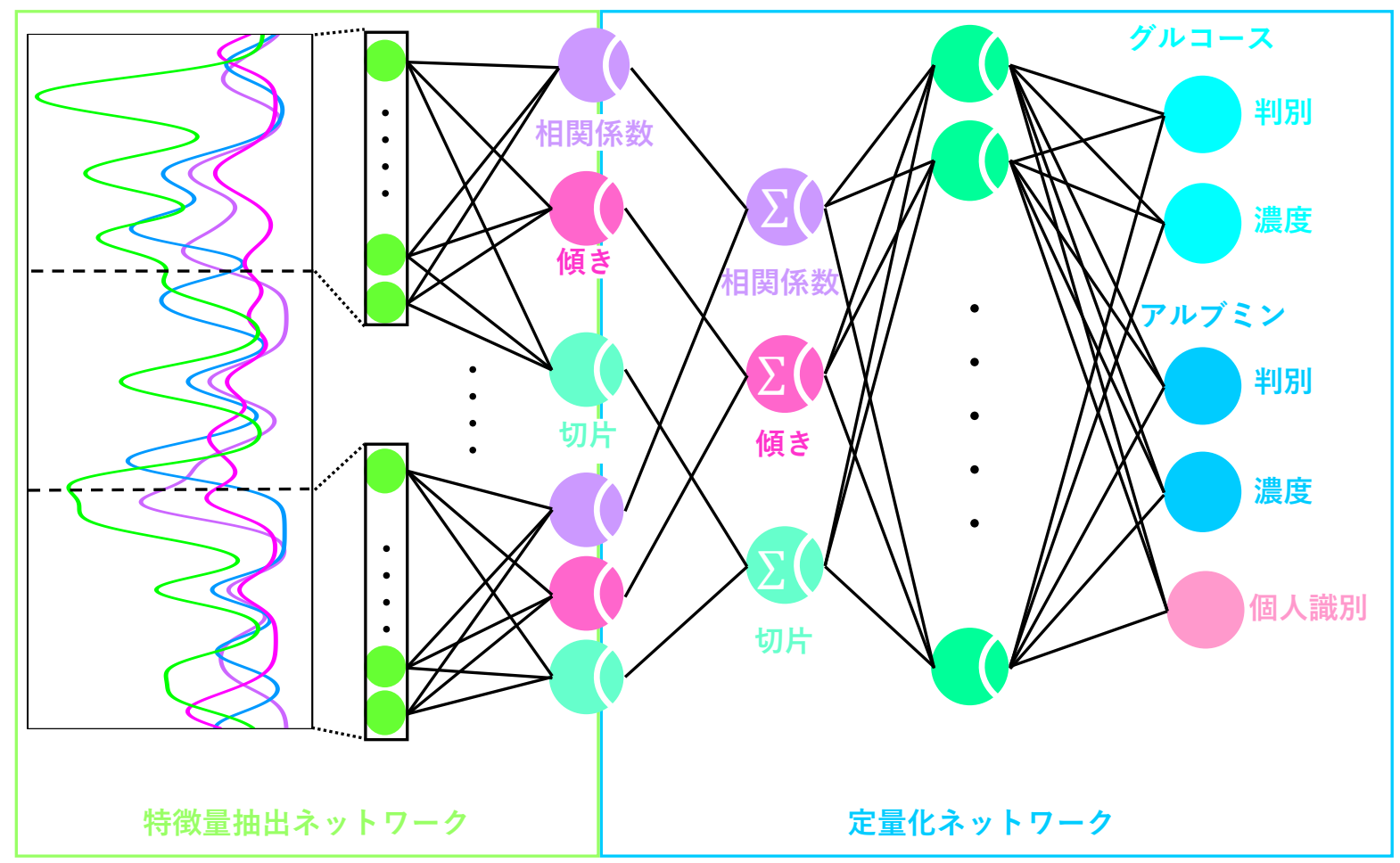

図1. 解析モデル全体の概要 
ンプレート画像とのマッチング度合い，回帰式の傾きは テンプレート画像との輝度值との倍率，回帰式の切片は 画像全体でのバックグラウンドの輝度值の差を示す．本 提案ではこの手法を一次元データに対して応用すること で，三つの特徵量となる相関係数と回帰式の傾き・切片 を得る.この得られた三次元特徴量をニューラルネット ワークの入力值とする. 特徴量抽出ネットワークで得ら れた特徵ピークをテンプレートとしてテストデータを正 規化相関した場合, 特徽量とした相関係数はテストデー タが特徵波形を持つかどうかの判定を行う。また他の特 徵量である回帰式の傾きと切片はこの特徵波形のピーク の相対強度に対する, テストデータのピークの相対強度 の倍率, 切片は特徵波形のバックグラウンドの相対強度 に対するテストデータのバックグラウンドの相対強度の 差を示す。

最後に定量化ネットワークでは特徵量抽出ネットワー クにより得られた相関係数と回帰式の傾き・切片を入力 值とし，ニューラルネットワークによりテストデータの 識別, 濃度などの定量的な評価を行う.

\section{$2 \cdot 2$ 誤差関数に相関係数を用いた特徵抽出}

特徵量抽出ネットワークでは初めに, 学習データを一 定の間隔で分割し，また学習によって特徴量を示すこと となる結合重みは始め乱数によって作成する. 次に, そ の結合重みと与える学習データを同じ一定の間隔で分割 する. 分割された区間ごとで，誤差関数に相関係数を用 いた勾配降下法を行い，重みを共有したネットワークで の学習により結合重みを相関係数が最大になるように更 新していく.

以下に一回の更新量を決める式の導出を示す。データ 数 $n$ の第 $j$ 番目 $(j=1, \ldots, n)$ の $d$ 次元の学習データを $x^{j}(i)(i=1, \ldots, d)$ と表し, この学習データの標準偏差を $S_{x}^{j}$ と表す. 結合重み $y(i)(i=1, \ldots, d)$ の標準偏差を $S_{y}$ と 表す。学習データ $x^{j}(i)$ と結合重み $y(i)$ の共分散を $S_{x y}^{j}$, 相 関係数を $r^{j}$ と表す.まず, 結合重み $y(i)$ がどれだけ学習デ 一タの特徴を表しているかを示す指針として以下の式 (1)のような誤差関数を定義する.

$$
E=\frac{1}{2} \sum_{j=1}^{n}\left(r^{j}-1\right)^{2}
$$

この誤差関数は，ニューラルネットワークでよく用いら れる二乗誤差関数の式に対して出力に当たるところを相 関係数，教師信号を 1 とした式である. 出力する相関係 数が教師信号である 1 にどれだけ離れているかを示し， 誤差関数Eが 0 に近づくほど与えた学習データと結合重 みy $(i)$ の形状が類似していることを示す.この誤差関数 $E$ を 0 に近づけるように結合重み $y(i)$ を更新するには, 誤 差関数 $E$ に対する特徵グラフ $y(i)$ の傾きを求めればよい ので, 学習係数を $\eta$ と表すと, 一回のグラフ $y(i)$ の更新 量は式(2)のように表せる.

$$
\Delta y(i)=-\eta \frac{\partial E}{\partial y(i)}
$$

ここで相関係数 $r^{j}$, 学習データの標準偏差 $S_{x}^{j}$, 結合重み $S_{y}$, 共分散 $S_{x y}^{j}$ は式(3)〜(6)のように示せる.

$$
\begin{gathered}
r^{j}=\frac{S_{x y}^{j}}{S_{x}^{j} S_{y}} \\
S_{x}^{j}=\sqrt{\frac{1}{d} \sum_{i=1}^{d}\left(x^{j}(i)-\bar{x}^{j}\right)^{2}} \\
S_{y}=\sqrt{\frac{1}{d} \sum_{i=1}^{d}(y(i)-\bar{y})^{2}} \\
S_{x y}^{j}=\frac{1}{d} \sum_{i=1}^{d}\left(x^{j}(i)-\bar{x}^{j}\right)(y(i)-\bar{y})
\end{gathered}
$$

$r^{j}$ は $y(i)$ の関数であるから誤差関数 $E$ に対する $y(i)$ の微 分は合成微分より式(7)のようになる.

$$
\frac{\partial E}{\partial y(i)}=\frac{\partial E}{\partial r^{j}} \frac{\partial r^{j}}{\partial y(i)}
$$

また，相関係数 $r^{j}$ の $y(i)$ に対する微分は商の微分法より 式(8)のようになる.

$$
\frac{\partial r^{j}}{\partial y(i)}=\frac{\frac{\partial S_{x y}^{j}}{\partial y(i)} S_{x}^{j} S_{y}-S_{x y}^{j} S_{x} \frac{\partial S_{y}}{\partial y(i)}}{S_{x}^{j^{2}} S_{y}^{2}}
$$

次に式(8)で必要とする, 共分散 $S_{x y i}$ に対する $y_{i}$ の微分と 標準偏差 $S_{y}$ に対する $y(i)$ の微分は式(9), (10)となる.

$$
\begin{gathered}
\frac{\partial S_{x y}^{j}}{\partial y(i)}=\frac{1}{m}\left(x^{j}-\bar{x}^{j}\right) \\
\frac{\partial S_{y}}{\partial y(i)}=\frac{y(i)-\bar{y}}{m S_{y}}
\end{gathered}
$$

以上の式(7)〜(10)を式(2)に代入することにより，グラフ $y(i)$ の一点一点に対し更新量を決定する式が求まる.

\section{$2 \cdot 3$ 区間内の相対強度の補正}

以上にまとめた学習のみでは相対強度が区間によって ずれてしまう問題が生じてしまう。この補正方法を述心゙ る. 結合重み $y(i)$ の相対強度を学習グラフ $x^{j}(i)$ の相対強 度に調整するには，結合重み $y(i)$ を相対強度軸方向に平 行移動し，縮小(または拡大)することで相対強度の補正 を行う。この平行移動量と拡大・縮小量は結合重みの相 対強度を縦軸, 学習データの相対強度を横軸とした散布 図で示し, その回帰直線の切片の分だけ結合重み $y(i)$ の 相対強度に対し平行移動させ，傾きの分だけ割れば，結 合重みの相対強度の補正が行える。この計算を式(11)に 示す. 式(11)の before $y$ は補正前の結合重みの相対強度を 示し, after y は補正後の結合重みの相対強度を示し, $\alpha$ は 学習データと特徵グラフの回帰式の傾きの平均を示し, 及は回帰式の切片の平均を示す.

$$
\text { after } y=(\text { before } y-\beta) / \alpha
$$

この縦軸の補正を特徴グラフが取得できた区間ごとに対 して処理していく. 


\section{$2 \cdot 4$ 正規化相関により得られる三次元特徵量}

次に, 図 2 に示すようなデータを用いて正規化相関に ついての説明を行う。テストデータと結合重み，二つの グラフの同じ波長に対し，それぞれの相対強度を新たな 二次元のグラフにプロットする. この新たなグラフの横 軸を結合重みの相対強度, 縦軸をテストデータの相対強 度とする。これを，結合重みが取れている範囲（0 とな っていない範囲）すべての值に対して行う。こうして作 成された新しいグラフの相関係数と回帰式の傾きと切片 をニューラルネットワークの入力值とする.この処理か らわかるように，相関係数はテストデータと結合重みの
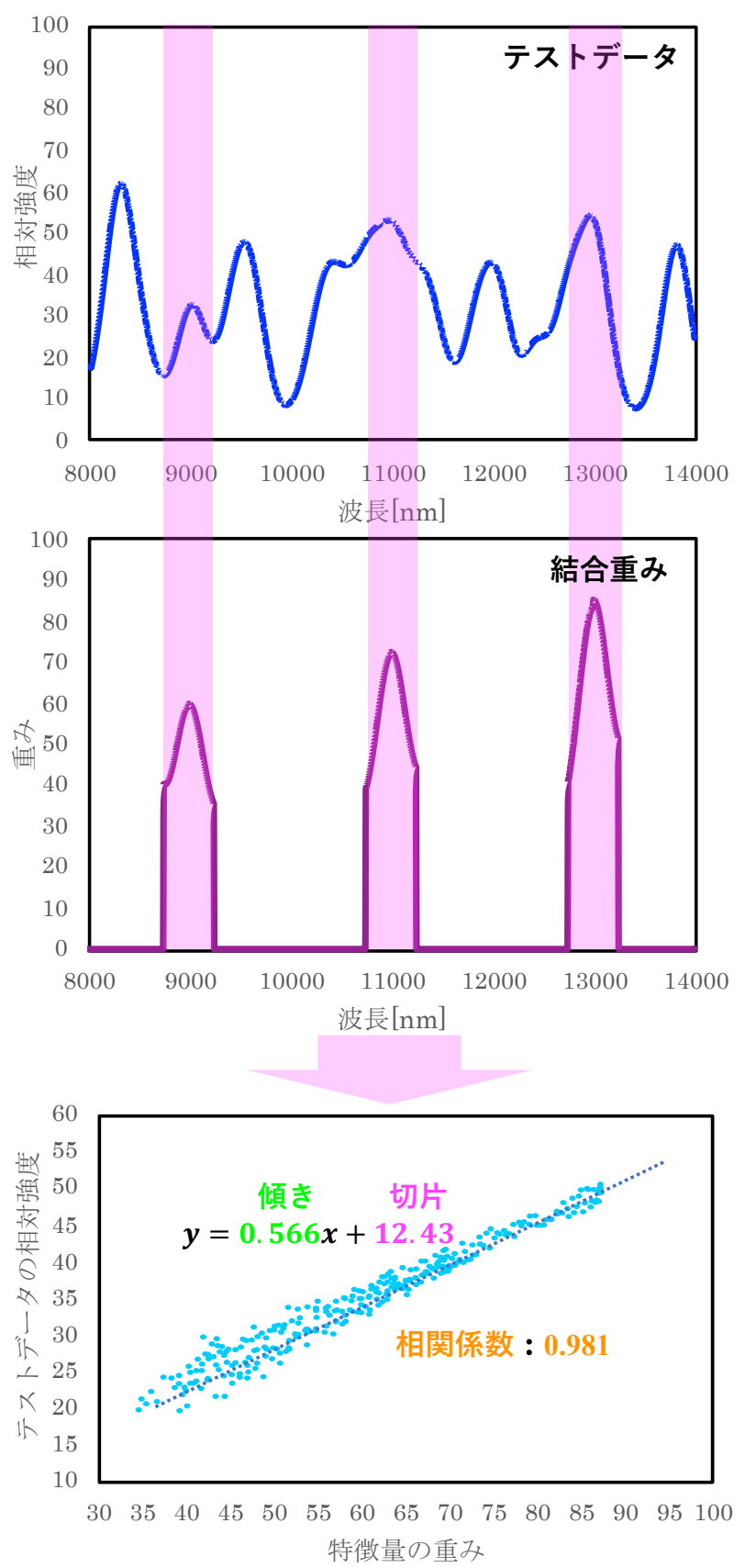

図2、正規化相関により得られる 相関係数，回帰式の傾き・切片の例

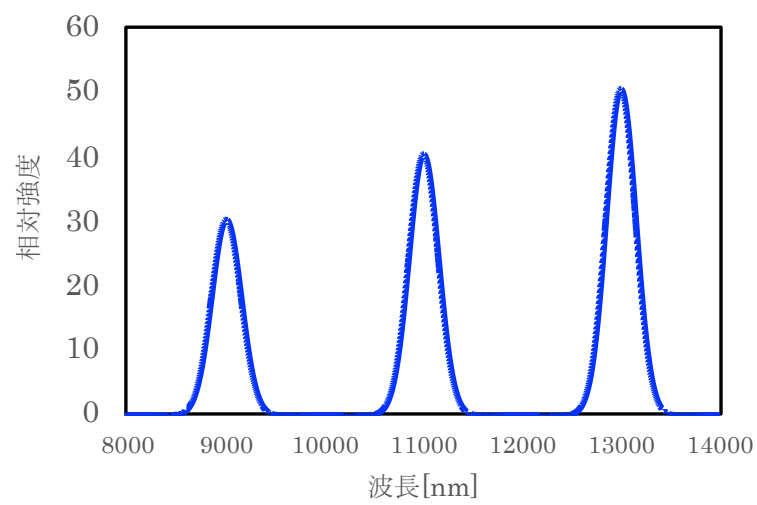

図3.人工データに与えた特徵量

形状の類似度を示し，回帰式の傾きはテストデータの結 合重みに対する倍率，回帰式の值がテストデータの結合 重みに対するバックグラウンドの相対強度の差を示すこ とがわかる，つまり，相関係数によってこのテストデー タの識別を行えることがわかる。

\section{3. 人エデータを用いた特徵量抽出実験}

\section{$3 \cdot 1$ 特徵抽出を行う人エデータ作成}

二種類の高次元人工データを用いて，提案手法である 機械学習により特徴量となる結合重みを抽出する実験を 行い，この機械学習の有效性を検討する．まず生成した 二種類の人工データ（低ノイズデータ, 高ノイズデータ とする）について説明する．生成した人工データは縦軸 を相対強度, 横軸を波長とした赤外スペクトルを模擬し たデータである。まず，図 3 に示寸ようなそれぞれの人 エデータの同じ位置に現れるピークを特徽量として三つ (図 3 左のピークから特徵量ピーク 1 , 特徵量ピーク 2 , 特徴量ピーク 3 とする）を生成した。 この特徴量は正規 分布の形を基に作成していて，ピークの波長の位置は正 規分布の平均值で設定し，ピークの山の幅は分散で設定 し，ピークの高さも正規化相関に係数をかけることで設 定した。この，三つの正規分布の平均值，分散，ピーク 最大值の三つのパラメータは表 1 亿示寸. 特徴抽出層で はこの図 3 に示寸結合重みを抽出できればよいこととな る。また，人工データにはそれぞれにノイズとして，正 規分布を低ノイズデータには 20 個，高ノイズデータに は 30 個与えた.このノイズとした正規分布のパラメー 夕は低ノイズデータでは表 2 で示寸範囲から高ノイズデ 一タでは表 3 に示寸範囲から一様乱数によって与えた. 最後にこのノイズを与えたデータに対し, 相対強度（縦 軸方向）に平行移動し, 等倍を行った. この平行移動, 等倍の值は低ノイズデータ, 高ノイズデータどちらに対 しても表 4 に示寸範囲から一様乱数によって与えた. 以 上のように作成し，実際に実験に用いた 5 ずつ人工デー 夕が含まれる低ノイズデータ，高ノイズデータはそれぞ れ図 4, 図 5 に示寸. 図 4, 図 5 の赩で示されている 範囲はそれぞれの人工データに与えている特徴量であり。 


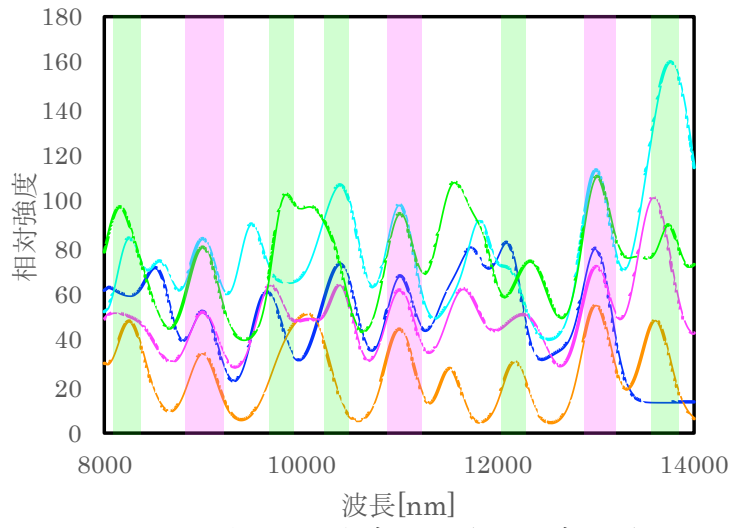

図4. 低ノイズデータ（人工データ）

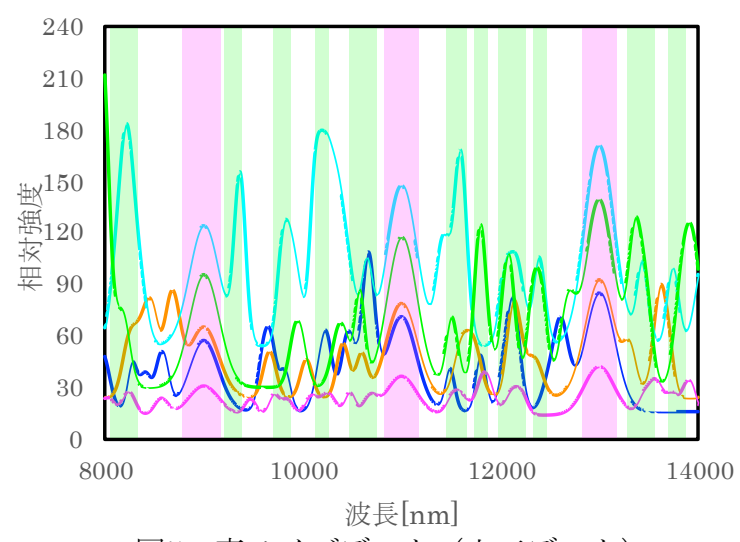

図5. 高ノイズデータ（人工データ）

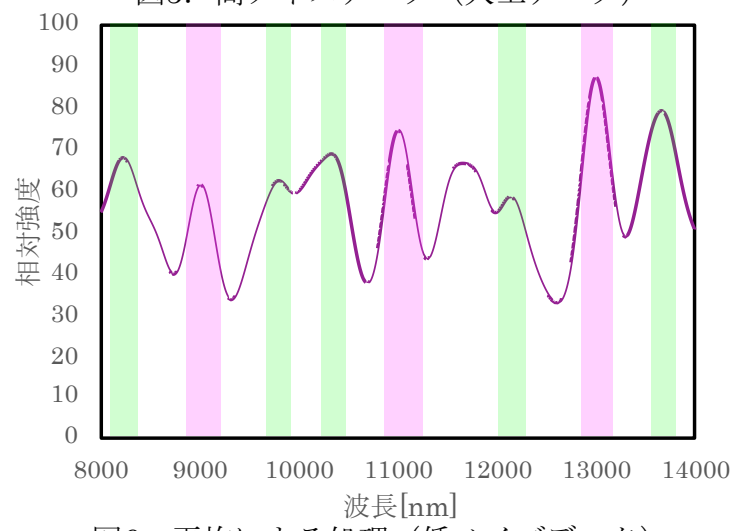

図6. 平均による処理（低ノイズデータ）

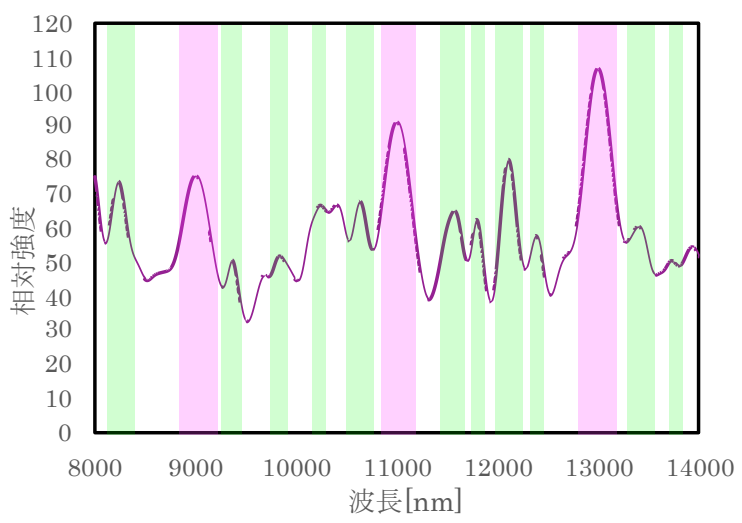

図7. 平均による処理（高ノイズデータ）
表1. 特徵量とした正規分布のパラメータ

\begin{tabular}{|r|c|c|c|}
\hline & 特徴量ピーク1 & 特徵量ピーク 2 & 特長量ピーク3 \\
\hline 平均値 & 9000 & 11000 & 13000 \\
\hline 分散 & 150 & 150 & 150 \\
\hline ピークの最大値 & 30 & 40 & 50 \\
\hline
\end{tabular}

表2. 低ノイズデータのノイズのパラメータ範囲

\begin{tabular}{|r||c|c|}
\hline データセット 1 & 最小 & 最大 \\
\hline \hline 平均 & 7000 & 15000 \\
\hline 分散 & 100 & 200 \\
\hline ピークの最大值 & 10 & 30 \\
\hline
\end{tabular}

表3. 高ノイズデータのノイズのパラメータ範囲

\begin{tabular}{|r||c|c|}
\hline データセット2 & 最小 & 最大 \\
\hline \hline 平均 & 7000 & 15000 \\
\hline 分散 & 50 & 80 \\
\hline ピークの最大值 & 15 & 25 \\
\hline
\end{tabular}

表4. データの平行移動・等倍の範囲

\begin{tabular}{|r||c|c|}
\hline \hline & 最小 & 最大 \\
\hline 等倍 & 0.5 & 2.4 \\
\hline 平行移動 & 0 & 30 \\
\hline
\end{tabular}

緑色で示されている範囲は 5 つの人データを平均した 場合に抽出されてしまうピークの範囲を示している. 本 研究では，この赤色の範囲の特徴量のみを抽出すること を目的としている. また, 平均による抽出の欠点は以下 の $3 \cdot 2$ 節で述べる.

\section{$3 \cdot 2$ 平均による処理の欠点}

作成した人工データの低ノイズデータと高ノイズデ 一タから図 3 のような特徵量となるピークを抽出する方 法として単純に平均することが考えられる，そこで実際 に平均して得られたグラフを図 6 , 図 7 に示す. 図 6, 図 7 の赤色で示された範囲が抽出したい特徵量であるが, 平均による処理では他の緑色で示す範囲でもピークが検 出されてしまっている.このように平均による処理では, どのピークが真に特徵量であるかわからず, このまま図 1 に示すような定量化ネットワークによって学習するに しても汎化能力は向上しない.つまり, 新たな機械学習 ではこの図 6 , 図 7 に示す赤色の範囲の真に特徴量とす るところのみを抽出しなくてはならない.

\section{$3 \cdot 3$ 特徵量抽出実験の結果}

提案する機械学習によって, 実際に人工データである 低ノイズデータと高ノイズデータに対して特徴量抽出実 験を行った結果を示す。まず，それぞれのデータに対し ては波長帯域 8000～14000[nm]を波長間隔 $5 \mathrm{~nm}$ ずつ離 散化した 1201 点を入力值とした. それぞれのデータセ ットに対する学習時のパラメータは, 両データセットに 対する学習率は 0.1 とし, 初期の結合重みは[0,0.1]の範 囲の一様乱数によって設定した. 区間分割は低ノイズデ ータに対しては 50 点, 高ノイズデータに対しては 40 点 


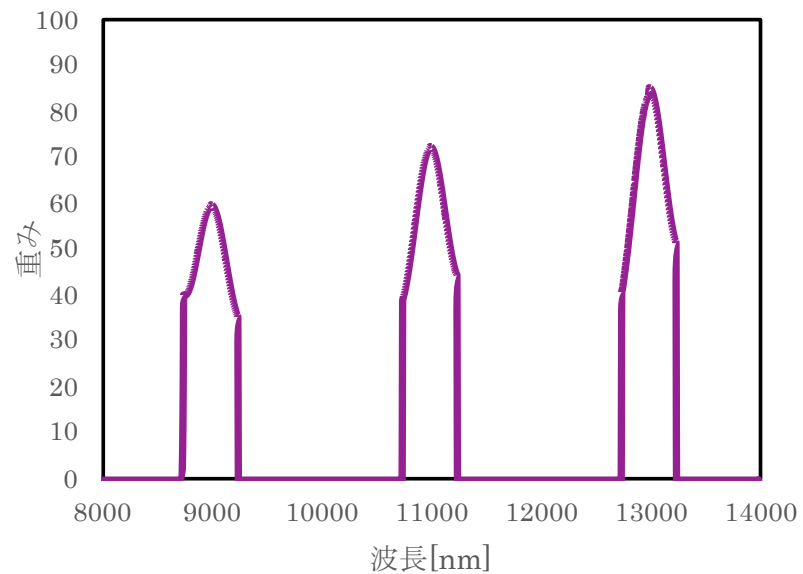

図8. 低ノイズデータから得た特徵量

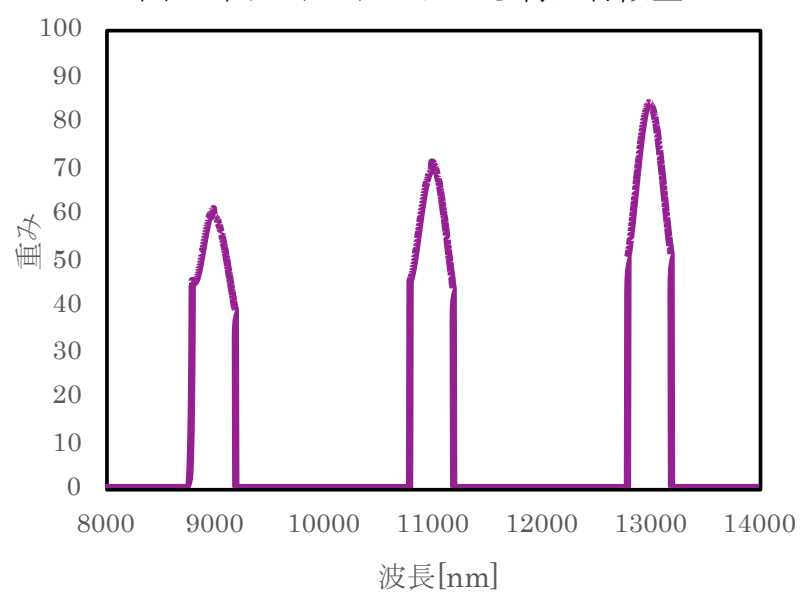

図9. 高ノイズデータから得た特徵量

に分けて学習を行った. epoch 数はそれぞれの区間で 10000 回とし，その時に得られた結合重みとそれぞれの データの相関係数の平均が 0.95 を超えた区間では結合 重みを特徽量として抽出し, 超えない場合は 0 を代入し た. 使用した Optimizer はそれぞれバッチ学習とした. 低ノイズデータ，高ノイズデータそれぞれに対して学習 を行い得られた結合重みを図 8 , 図 9 に示寸。低ノイズ データから抽出した特徵量のそれぞれのピークは左のピ 一クから波長位置 9000[nm], 11000[nm], 13000[nm]で 取得することができ，高ノイズデータからは波長位置 8995[nm], 11000[nm], 12995[nm]で取得することがで きた. 図 3 に示すように人工データにあらかじめ与えて ある特徵量としたピークの波長位置は 9000[nm], $11000[\mathrm{~nm}], 13000[\mathrm{~nm}]$ であるので，それぞれ学習によ って得た特徴量は人工データに予め与えていた特徴量と ほぼ同じ波長位置で特徽量を抽出できたとわかる。よっ て, 提案手法である新たな機械学習より人工データから 特徵量抽出に成功したと言える。しかし，相関係数に閾 值を設け収束しない場合に 0 を代入するという方法は作 為的である．そこで，低ノイズデータに対して L2 正則 化[Horel 70]により, 特徵量とならない結合重みを 0 に 自然に収束させる実験を行った. L2 正則化を用いて学習

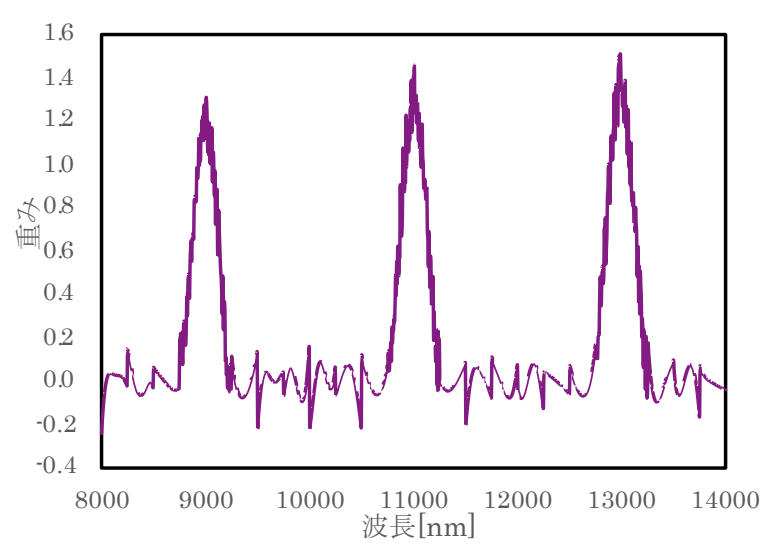

図10. L2正則化により得た特徵量

を行う際の一回の更新量は以下の式(12)のように表され る.

$$
\Delta y(i)=-\eta \frac{\partial E}{\partial y(i)}-\lambda y(i)
$$

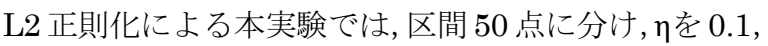
入を 0.001 とし Epoch 数はそれぞれの区間 10000 回で Optimizer はバッチ学習とした。 以上の方法により低ノ イズデータに学習を行った結果を図 10 に示す. 図 10 に 示すように, $9000[\mathrm{~nm}], 11000[\mathrm{~nm}], 13000[\mathrm{~nm}]$ あたり で特徵量が取れているように見えるが，この得られた結 合重みによって, 全体のネットワークにおける後半部分 の定量化ネットワークの学習を行う際，特徵量となる区 間ではない 0 付近に值をとる区閒からも相関係数，回帰 式の傾き・切片を抽出してニューラルネットワークの入 力值としてしまう問題が生じてしまうため, 本研究では そのまま 0 を代入する方法を取ることにした.

\section{4. 実赤外スペクトルデータの特徵量抽出実験}

実際に在宅で手軽に使用できると考えられる小型の分 光イメージング装置 (メーカー: アオイ電子, 波長帯域: 8000 14000[nm]) から実際に得られたデータ[Kitazaki 18]を本提案手法である機械学習によって分析を行った 結果を示す。 小型装置の測定対象物は，人体の代わりに

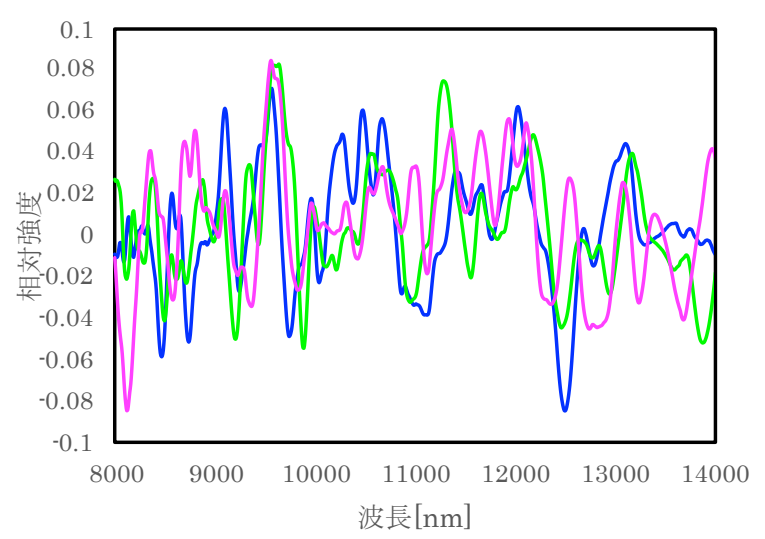

図11. 小型装置から得られた赤外スペ クトル（実データ） 


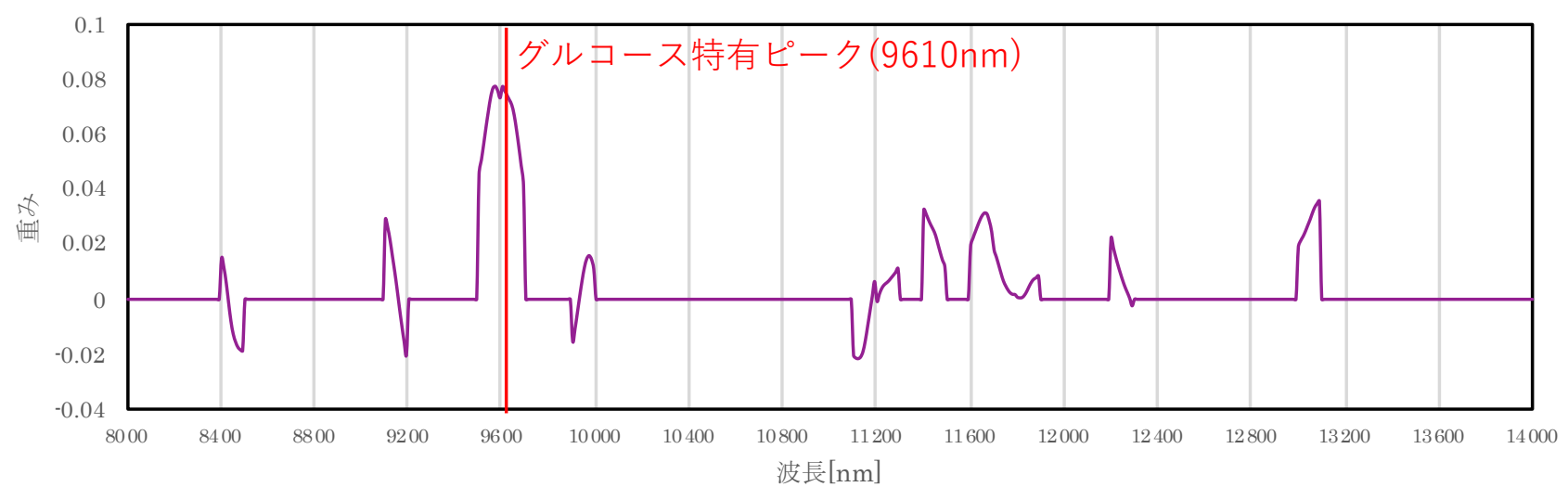

図12. 実データから得られた特徴量

人体の水分量の近い寒天とした。この寒天には水とグル コースのみから作られており，この計測されたデータか らは，グルコースの特有ピークである $9610[\mathrm{~nm}]$ 付近に 特徴量が取れれば良いこととなる. 小型装置から得られ た赤外スペクトルを図 11 に示す。このデータは同条件 の同対象物に対して 3 回測定し得られたデータである. 波長帯域は 8000〜 14000[nm]の 10[nm]ごとの波長間隔 に離散化した 601 点を入力值とした. 学習率は 0.1 とし, 初期重みは[0,0.1]の一様乱数により設定した。 区間分割 は 10 点に分けて学習を行った. epoch 数はそれぞれの 区間で 10000 回とし，その時に得られた結合重みとそれ ぞれのデータの相関係数の平均が 0.95 を超えた区間で は結合重みを特徵量として抽出し, 超えない場合は 0 を 代入した. 使用した Optimizer はバッチ学習とした. 以 上のパラメータにより得られた特徵量を図 12 に示す.

図からわかるようにグルコースの特有ピークが 9610[nm]付近にあるのに対して, 得られた特徽量のピー ク相対強度が強いものとして波長位置 $9570[\mathrm{~nm}]$ と 9600[nm]でピークを抽出した.よって実データから, 機 械学習によってグルコースの特有ピークに近いところで ピークを持つ特徵量の抽出ができたことがわかる．しか し, 問題としてグルコースの特有ピーク以外にも細かく 特徴量としてピークが抽出されてしまっていることがあ る.これは, それぞれのデータのノイズが重なってしま い偶然に抽出されてしまったと考えられる，本論文では 3 データから特徵量を抽出しているが，単純にデータが 増えればこのようなことは起こり難くなると考えられる.

\section{5. おわりに}

本論文では複数のスペクトルに対して，特徵的なピー クのみを特徵量として抽出することにより, データを圧 縮し, 数少ないデータにより判断をできる手法の提案を した。 また実際に人工データと小型装置から取得したデ 一夕の両方から提案手法より特徵量の抽出を行い, その 有効性を示した。 今後は他の事例, 例えば病気の発生ま での時系列データの特徴波形, 株価の暴落に対する時系 列の特徵波形,など新たな発展の可能性を探るとともに,
この提案手法の区間分割や特徵量の取れないところで 0 を代入するような人為的なところを自動で行えるような ネットワークのモデルを作りたい.

\section{参考文献}

[Barnea 76] Barnea, D. I., and Silveman, H. F.: A class of algorisms for fast digital image registration, IEEE Transactions on Computers, 100.2, p.179(1972)

[Haselsteiner 00] Haselsteiner, E., and Pfurtscheller, G.: Using time-dependent neural networks for EEG classification, IEEE Transactions on Rehabilitation Engineering, 8.4 p.457(2000)

[Hoerl 70] Hoerl, A. E., and Kennard, R. W.: Ridge regression: Biased estimation for nonorthogonal problems, Technometrics, 12:1, p.55 (1970)

[Kelly 91] Kelly, M. F., Paker, P. A., and Scott, R. N.: Neural network classification of myoelectric signal for prosthesis control, Journal of Electromyography and Kinesiology, 1.4 p.229(1991)

[Kitazaki 18] Kitazaki, T., Kawasima, N., Yamamoto, N., Hiroyuki, N., Akira N., Wada, K., and Ishimaru, I.: Measurement of glucose concentrations inside agar using parametric standing wave to realize noninvasive blood glucose sensor, Optical Society of America Computational Optical Sensing and Imaging, JTu4A, p.18 (2018)

[Mistek 15] Mistek, E., and Lednev, I., K.: Identification of species' blood by attenuated total reflection (ATR) Fourier transform infrared (FT-IR) spectroscopy, Analytical and Bioanalytical Chemistry, 407.24, p. 7435(2015)

[Rumelhart 85] Rumelhart, D. E., Hinton, G. E., and Williams, R. J.: Learning internal representations by error propagation, California Univ San Diego La Jolla Inst for Cognitive Science, 8506 (1985)

[Rumelhart 86] Rumelhart, D. E., Hinton, G. E., and Williams, R. J.: Learning representations by backpropagating errors, Nature, Vol.323, Issue6088, pp.533 -536(1986)

[Sato 16] Sato, S., WeI, Q., Kawasima, N., Nogo, K., Hosono, A., Wada, K., Ishimaru, I.: Ultra-miniature one-shot Fourier-spectroscopic tomography, Optical Engineering, 02516 p.55(2016)

[Silver 87] Silver, W. M.: Normalized correlation search in alignment, gauging, and inspection, International Society for Optics and Photonics, 755, p.23(1987)

[担当委員 : 三宅 陽一郎〕

2018 年 4 月 28 日 受理 


\section{著 者 紹 介}

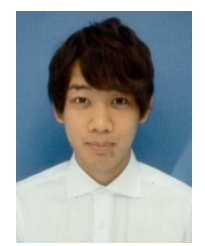

天谷 貴 (学生会員)

2014 年香川大学工学部知能機械システム工学

科入学, 2018 年 3 月同大学卒業. 同年 4 月筑波

大学大学院システム情報工学科社会工学専攻 入学.

\section{石丸 伊知郎}

1987 年大阪大学工学部卒業. 同年, (株) 日立製 作所, 2000 年香川大学助手, 2001 年同大学助 教授を経て, 2008 年より同大学工学部知能機 械システム工学科教授. 専門は主に医用生体工 学・生体材料学, レーザ・超音波計測, 知的制 御, 計測工学, 知能機械学・機械システム, 計 測工学. 